\title{
Commodifying Human Life: The Numerus Clausus Principle and Unconventional Property Rights
}

\author{
Joshua K. Wasylciw ${ }^{1} \&$ Scott Nicholas Romaniuk ${ }^{2}$ \\ ${ }^{1}$ Faculty of Law, University of Calgary, Calgary, Canada \\ ${ }^{2}$ Department of Politics and International Relations, School of Social Sciences, University of Aberdeen, \\ Aberdeen, UK \\ Correspondence: Scott Nicholas Romaniuk, Department of Politics and International Relations, School of Social \\ Sciences, University of Aberdeen, Aberdeen, AB24 3QY, UK. Tel: 44-122-427-2726. E-mail: \\ scott.n.romaniuk.11@aberdeen.ac.uk
}

Received: November 26, 2012 Accepted: December 11, 2012 Online Published: July 5, 2013

doi:10.5539/ilr.v2n1p102 URL: http://dx.doi.org/10.5539/ilr.v2n1p102

\begin{abstract}
Throughout the common law world the notion that classes of property rights are closed in number is a prevailing concept across property regimes. This closed in number, or numerus clausus, principle has served property rights well. This principle has prevented messy property arrangements from arising - such as an agreement between two people where one owns a watch on Tuesdays and Thursdays, and the other owns it the rest of the week. However, as technology evolves, property is created in items that the legislature never contemplated. In this article we explore the seminal Canadian case of JCM vANA and examine how numerus clausus and property no longer remain sufficient tools for delineating individual's rights to tangible goods. Whether the sperm straws in question in JCM are property or not, and whether numerus clausus recognizes a category of property rights where human tissues or fluids capable of providing life or not, are contentious issues, not easily resolved. The argument is made that the numerus clausus principle is of marginal use considering such forms of unconventional property as human gametes. This is supported through a review of JCM, followed by an exploration of the optimal standardization. The second part of this work seeks to demonstrate the incompatibility of the numerus clausus principle, and the optimal standardization theory, with a critical analysis of JCM that underscores three central but overwhelming critical problems with such an application.
\end{abstract}

Keywords: Gametes, human embryos, law of property, legislature, optimal standardization

\section{Introduction}

In their article "Optimal Standardization in the Law of Property: The Numerus Clausus Principle" Thomas Merrill and Henry Smith assert that the numerus clausus principle is a useful, if even imperfect, tool for striking a balance between the complete customization of forms of property and the standardization of property to one single form, such as the fee simple. (Note 1) Their argument is supported by an examination of how the measurement of cost externalities takes place using the useful paradigm of one hundred individuals, all of whom own one hundred different watches, and the ensuing transfer of rights to the watches between others. (Note 2) While this argument presents itself with considerable appeal, and one for traditional types of property, it happens to encounter problems when new types of property are conceived.

This is the case when taking into consideration the straws of sperm, which were at issue in the case of JCMv ANA. (Note 3) Accordingly, the argument presented here is that the numerus clausus principle as advanced by Merrill and Smith, is not as useful as they propose, particularly when taking into consideration such forms of unconventional property as human gametes. We establish this line of argumentation and support through a review of JCM, followed by an exploration of the optimal standardization. The second part of this work seeks to demonstrate the incompatibility of the numerus clausus principle, and the optimal standardization theory, with a critical analysis of JCM that underscores three central but overwhelming critical problems with such an application. 


\section{Literature Review}

While there has been a considerable amount of literature written on the topics of when life begins, and when life ends, the academic literature available on sperm as property is less prolific, however a surprisingly large among has still been written on the subject. One of the early authors concerned with this topic was Bonnie Steinbock. Writing over a decade ago, Steinbock argued, and Madam Justice Russell quoted in her decision in JCM v ANA that:

To characterise something as property suggests that certain things may be done with it... If there are entities though ought not to be treated in these ways, if, that is, there are good moral reasons why they should not be treated in these ways, then they should not be considered as property. (Note 4)

While Madam Justice Russell expressed sympathy with the argument, she eventually rejected this argument, and the arguments of two other academics citing that "the court is ill equipped to handle moral and philosophical arguments." (Note 5)

The second author that Madam Justice considered was Ernest Waintraub. Writing over a decade after Steinbock, Waintraub argued that previous (American) courts have taken the position that frozen embryos and other zygote and gametes are neither property nor persons but that they occupy an "interim category" of tangible items somewhere between life forms and property. (Note 6) As a result of this conclusion Waintraub supports the decision reached in Hecht where a testator's sperm vials were concluded to be property, and were bequeathed to the testator's girlfriend. Like Steinbock's argument, Madam Justice Russell was not willing to accept Waintraub's on the basis that it was not for the court to decide philosophical questions. Additionally, Madam Justice Russell rejected Waintraub's argument as it advanced the argument that these types of disputes may be better settled in other areas of law (such as tort) and there was no such claim made in JCM.

The third, author considered in JCM, Heidi P. Forster, reached four general conclusions regarding the law and frozen embryos:

1. Embryos are considered neither persons nor property, but "special entities" that have the potential to become persons and, therefore, warrant respect;

2. Pre-procedural agreements between couples regarding the disposition of the embryos should be considered in a binding contract;

3. In the absence of such an agreement, the party wishing to avoid procreation should be awarded the embryos, except in circumstances where the other party has no other way of becoming a parent; and

4. The rights of both donors should be considered equally. (Note 7)

In addition to rejecting these arguments for fear of the court wading into a philosophical debate Madam Justice Russell also rejected Forster's argument as it examined the same American cases as the claimant did, and Madam Justice "did not find the US cases cited by the claimant to be of much assistance in this case." (Note 8)

Much of the literature which was not considered by JCM focuses on the seminal American case of Davis and would likely have little effect on courts in Canada should a similar issue be decided in a contemporary case. Mark Pieper's "Frozen Embryos" (Note 9) largely echoes what Forster's piece establishes, as does Alexander Capron's "Parenthood and Frozen Embryos." (Note 10) However there is an emerging interest in this field among Canadian authors, including Maneesha Deckha who argues, that the legislative restrictions in the Canada Assisted Human Reproduction Act on embryo research are indicative of a Parliament that respects women's reproductive autonomy and which that embryos are much closer to property then to any other category. (Note 11)

From this brief review of the literature available on frozen embryos emerges a trend that appears to suggest that academics feel that it would be appropriate to treat frozen gametes and zygotes as property for the purposes legal disputes. Although courts in the United States have been willing to accept this argument since at least Davis in 1992, courts in Canada remain much more sceptical and have yet to subscribe to this reasoning. Madam Justice Russell rejected this argument in JCM in 2012, and there remains no reason to think that her decision would be overturned on appeal.

\section{Review of JCM}

The facts found within $J C M$ depict, in simple terms, a couple unable to conceive on their own that purchased straws of sperm from a sperm bank and conceived two children. (Note 12) Following the conception of these children, the relationship between the two dissolved. (Note 13) Subsequently, an agreement was made regarding the separation of property that accumulated throughout the course of the relationship, however the remaining thirteen straws of sperm were inadvertently overlooked and excluded from the agreement. (Note 14) Following the dissolution of the original relationship between $\mathrm{J}$ and $\mathrm{A}$, J initiated another relationship with a third party. (Note 15) 
$\mathrm{J}$ and the third party wanted to use some of the sperm from the remaining straws to conceive a third child, which would be partly related to the first two children. (Note 16) This proved to be a rather contentious decision as A objected to the idea and requested that the remaining straws be destroyed. (Note 17) The failure of reaching an agreement between $\mathrm{J}$ and $\mathrm{A}$ regarding the destruction of or even how to deal with the excess the straws, went before a court for a judge to decide what would become of the straws. (Note 18)

At the crux of $J C M$ was the question of whether or not the sperm in the straws could rightfully be considered property or not. (Note 19) While in the end Russell found that they were property and that they were to be treated as any other jointly acquired property during the course of a spousal relationship, A introduced a measure of case law from previous jurisdictions that found that the sperm were not property per se, rather that "pre-embryos are not, strictly speaking, either 'persons' or 'property,' but occupy an interim category that entitles them to special respect because of their potential for human life." (Note 20) It is this interim category, which the numerus clausus principle has a significant amount of difficulty tackling, and which will be addressed within the following pages.

\section{Optimal Standardization and Numerus Clausus}

According to Merrill and Smith, the numerus clausus principle can be explained based upon an optimal standardization of property rights. (Note 21) They assert that when individuals wish to obtain rights to property from another person, when individuals wish to avoid infringing upon the property rights of another person, or when the individual encounters property rights in any manner, the individual will measure the cost of doing so. (Note 22) When it is found that the cost of measurement is less then the cost of the goal (to acquire property rights or to avoid infringing property rights) then the individual will proceed along that course. However, when the cost of measurement is greater than the goal, then the individual will not bother to pursue the acquisition of the property rights in question. (Note 23)

In order to illustrate this in practical terms, Merrill and Smith utilize the example of a fictitious property right being created in a watch based upon what day of the week it is. (Note 24) The author's then assert that this type of a property right is impractical because of the costs that will be imposed upon the other ninety-nine watch owners. (Note 25) As a result, it is argued that the numerus clausus principle is a useful mechanism with which to prevent the fragmentation of property rights and the resultant increased communication costs while continuing to allow enough flexibility so as to customize property in a manner that fit the most common needs of property rights holders. (Note 26) While this theory is a practical justification for having a closed number of property rights, it loses its appeal when applied to unconventional forms of property, as in JCM.

\section{Problem with Optimal Standardization and Numerus Clausus in JCM}

\subsection{The Commodification of Human Life}

One of the most glaring problems with respect to applying Merrill and Smith's theory of optimal standardization to the facts in JCM is the moral issue surrounding the commodification and economization of human life. Following in the economic style of Harold Demsetz, (Note 27) the authors assert that the costs of property can be measured and balanced, and a utilitarian decision made based upon the difference between cost and benefit. (Note 28) Casting aside the difficulty with actually calculating and measuring some of the more proximal costs, which are readily apparent, the uncomfortable situation where human life must be measured and calculated, as was advanced by the respondent in $J C M$, remains a poignant challenge.

While Russell, J. was ultimately not persuaded by this argument, when opining on whether or not sperm could be rightfully deemed property, she did offer the statement that, "the court is ill equipped to handle moral and philosophical arguments. While I appreciate the approach suggested by Dr. Steinbock, it is not the role of the court to choose the correct approach to such existential questions." (Note 29) In rejecting the respondent's argument in this way, Russell, J. suggests that there is a problem with the current property regime when it comes unconventional property, such as sperm and embryos, which must be addressed (although by an institution other then the court). The suggestion that this is an issue that must be dealt with by an external institution (such as the legislature) reveals that the optimal standardization of property rights was not met with the current property regime, or else there would be no need for intervention by another body to resolve the moral questions involved. Consequently, the numerus clausus principle required adjustment so as to include (or to specifically exclude) additional forms of property rights involving human embryos and gametes.

\subsection{Numerus Clausus Does Not Help to Define "What is Property?"}

A second, larger, issue that is present in Merrill and Smith's theory, and that is compounded in JCM is that neither the authors, nor Russell, J., specifically address the concept of property in this case. Instead both the authors and Russell, J. accept that property exists, without putting forward any type of operational definition. They 
subsequently attempt to fit property into one of the numerus clausus property boxes, which have already been established. In Merrill and Smith's article, the question of what characteristics or qualities something must have before it is considered property is overlooked in its entirety. Their article implies that items are appropriately considered property when they fit into one of the numerus clausus boxes. (Note 30) Instead of talking about why a watch is property, its status is simply presupposed. As such, those involved move forward by attempting to force the watch into different types of property boxes.

When this act of placing property into specific boxes is extended to the sperm straws at issue in $J C M$, the straws fail to fit neatly into one of the numerus clausus boxes. Indeed, the first paragraph of analysis on the first issue (is the sperm property?) is not analysis at all. Rather, it may be seen as a simple apology from Russell, J. on how she must dehumanize the nature of the sperm in order to make it fit into a preconceived notion of property and thus, to adjudicate the dispute accordingly. (Note 31) Russell, J. however, seemed intent upon forcing the sperm straws into a property category, despite their awkward fit, and maintaining that they were property even in spite of their unconventional characteristics. (Note 32) In the end, Russell, J. determined simply that the sperm were in fact property because they were considered so even prior to coming into the current owner's possession. (Note 33)

Using the Canadian case of $C C v A W$ (Note 34), Russell, J. reasoned that the sperm in JCM were property. (Note 35) In analogizing $C C$ Russell, J. stated that, "the sperm became the property of the plaintiff to do with as she chose once it was given to her." (Note 36) However, for the sperm to become the plaintiff's property once it was given to her, it must have been the property of the person who was giving it to her first. As a result, Russell, J. accepted that the property in $C C$ was the plaintiff's property given the act that it was property before it was handed over. This circular reasoning thus becomes, at best, an exercise aimed at forcing sperm to fit into one of the previously established numerus clausus boxes. By doing so, the optimal standardization of property rights is maintained, measurement costs are detained at a minimal lever, communication costs are kept low, and a decision on the issue before the court can be rendered.

Employing the British case of Jonathan Yearworth and Ors $v$ North Bristol NHS (Note 37), Russell, J. reasoned that, "the men's sperm [w]as property on the basis that the men were the donors of that semen." (Note 38) Later, when the sperm were damaged by the failed cooling system, the court accepted that the frozen sperm were property of the men because they have previously owned it before donating it. (Note 39) However determining whether or not the sperm fit into one of the previously established property paradigms does not help to answer the question "what is property?" in order to determine if other items are also considered property. Instead, once again we see Russell, J. accepting an argument that the property is so because it fulfilled such a status previously. While the conclusions in Yearworth and in $C C$ that the sperm fit into previously established property regimes - or into previously established numerus clausus boxes - may have been correct, their fit into these regimes and boxes does not help to answer the question at the heart of JCM.

\subsection{Other Categories of Property Rights Were Identified in JCM}

The third major issue which is present when applying Merrill and Smith's theory to the facts and analysis in JCM is that types of property rights which do not fit into previously established numerus clausus boxes were recognized by several courts cited in JCM. (Note 40) While Merrill and Smith contend that numerus clausus helps to create a balance between completely customizable property rights and wholly regimented property rights, which is sufficient for our needs, $J C M$ illustrates that this is not true. Within the $J C M$ decision, the American cases of Hecht, (Note 41) Moore, (Note 42) and Davis (Note 43) were all adjudicated upon the basis that human biological materials occupy an interim space between property and not property, and are thus, deserving of special treatment before the courts. (Note 44) As previously discussed, this was a line of argument that summarily Russell, J. rejected. However, other judges have recognized these unique types of property rights. Whether Russell, J. is correct, or whether her American counterparts are correct, remains to be settled. However, for the time being, some judges have recognized these rights, which do not fit into any of the previously established property rights paradigms.

Although Russell, J. was able to maintain that the sperm in issue in $J C M$ was property without expanding current types of property rights, she did so with apprehension. (Note 45)Noting that the within American cases, "embryos have more 'potential for human life' than a gamete alone. Accordingly, the argument that sperm is in the same 'interim category' between person and property is not as compelling," Russell, J. did two things. (Note 46) First, she recognized that a fertilized embryo, having potential for life, is in a different property category than sperm is prior to fertilization of an ovum. Second, while noting that the interim argument was not as compelling for the $J C M$ case, she did not discard it altogether. Although she did not adopt it in JCM in a future case, more aligned with the facts within the American cases, Russell, J. may yet adopt the interim argument. As a result of this, American cases 
that substantiate the interim, and special property rights involved with sperm, a new category of property rights seems to be emerging. Thus, Merrill and Smith's numerus clausus principle and theory of optimal standardization will likely need to make way for this evolving property right.

\section{Conclusion}

Merrill and Smith theorize that having a closed number of property rights assists in the maintenance of an optimal standardization between completely customizable property rights and completely regimented property rights. (Note 47) This optimal standardization allows for the measurement and cost of externalities to be kept at a minimum as well as for the reduction of information costs, both of which would be much higher in a system with completely customisable property rights. (Note 48) While their theory offers justification for keeping the number of property rights closed for conventional property, it remains unable to justify the continuation of the numerus clausus principle when unconventional property types are encountered, such as with the sperm at issue in the JCM case.

In order to substantiate this claim, this work has reviewed both the JCM case and the theory of optimal standardization and numerus clausus. Following this, an application of Merrill and Smith's theory to JCM was made, which highlighted the problems evident when applying the theory to unconventional property. Within the three primary problems that were explored earlier, we find that optimal standardization commodifies human life, numerus clausus does not help to define what is property, and that JCM identified special and interim property rights to sperm that current property law does not recognize. Firmly conjectural ground is comprised of these three issues when taken together regarding whether what Merrill and Smith assert about optimal standardization and numerous clausus can be considered accurate. The argument and examples presented within the preceding text indeed shows that it is not.

\section{References}

Capron, A. (1992). Parenthood and Frozen Embryos: More Than Property and Privacy. The Hastings Center Report, 22(5), 32-33. http://dx.doi.org/10.2307/3562142

Deckha, M. (2012). Legislating Respect: A Pro-Choice Feminist Analysis of Embryo Research Restrictions in Canada. McGill L Journal, 58(1), 199. http://dx.doi.org/10.7202/1013389ar

Demsetz, H. (2012). Toward a Theory of Property Rights. In G. S. Alexander, \& H. Dagan (Eds.), Properties of Property. New York, NY: Wolters Kluwer Law and Business

Forster, H. P. (2000). Law and Ethics Meet: When Couples Fight Over Their Frozen Embryos. Journal of Andrology, 21(4), 512.

Merrill, T. W., \& Smith, H. E. (2012). Optimal Standardization in the Law of Property: The Numerus Clausus Principle. In G. S. Alexander, \& H. Dagan (Eds.), Properties of Property. New York, NY: Wolters Kluwer Law and Business.

Pieper, M. (1990). Frozen Embryos: Persons or Property? Creighton L Rev, 23(4), 807.

Steinbock, B. (1995). Sperm as Property. Stan L \& Pol'y Rev, 6(2), 57.

Waintraub, E. (2007-2008). Are Sperm Cells a Form of Property? A Biological Inquiry into the Legal Status of the Sperm Cell. Quinnipiac Health L J, 11, 1 .

\section{Cases}

CC v AW, 2005 ABQB 290, 50 Alta LR (4th) 61.

Davis v Davis, 842 SW (2d) 588 (Sup Ct 1992).

Hecht v The Superior Court of Los Angeles County, 16 Cal App (4th) 836 (Ct App 1993).

JCM v ANA, 2012 BCSC 584, 33 BCLR (5th) 140.

Jonathan Yearworth and Ors v North Bristol NHS, [2009] EWCA Civ 37.

Moore $v$ Regents of the University of California, 51 Cal (3d) 120 (Sup Ct 1990).

\section{Notes}

Note 1. Merrill, T. W. and Smith, H. E. "Optimal Standardization in the Law of Property: The Numerus Clausus Principle," in Properties of Property (Alexander, G. S. and Dagan, H. eds, New York, NY: Wolters Kluwer Law and Business, 2012): 110 at 118. 
Note 2. Ibid. at 113-116.

Note 3. JCM v ANA, 2012 BCSC 584, 33 BCLR (5th) 140 [JCM].

Note 4. "Sperm as Property" (1995) 6:2 Stan L \& Pol'y Rev 57.

Note 5. JCM, supra note 3, 140 at para 68.

Note 6. "Are Sperm Cells a Form of Property? A Biological Inquiry into the Legal Status of the Sperm Cell" (2007-2008) 11 Quinnipiac Health LJ 1.

Note 7. "Law and Ethics Meet: When Couples Fight Over Their Frozen Embryos" (2000) 21:4 Journal of Andrology 512.

Note 8. JCM, supra note 2 at para 65.

Note 9. "Frozen Embryos: Persons or Property?" (1990) 23:4 Creighton L Rev 807.

Note 10. "Parenthood and Frozen Embryos: More Than Property and Privacy" (1992) 22:5 The Hastings Center Report 32-33.

Note 11. "Legislating Respect: A Pro-Choice Feminist Analysis of Embryo Research Restrictions in Canada" (2012) 58:1 McGill L Journal 199.

Note 12. JCM, supra note 3 at para 2-17.

Note 13. Ibid.

Note 14. Ibid.

Note 15. Ibid.

Note 16. Ibid.

Note 17. Ibid.

Note 18. Ibid.

Note 19. Ibid. at para 19-20.

Note 20. JCM, supra note 3 at para 31.

Note 21. Merrill, supra note 1 at 113.

Note 22. Ibid.

Note 23. Ibid.

Note 24. Ibid. at 113-116.

Note 25. Ibid. at 113-116.

Note 26. Ibid. at 113-116.

Note 27. See, Demsetz, H. "Toward a Theory of Property Rights," in Properties of Property (Alexander, G. S. and Dagan, H. eds, New York, NY: Wolters Kluwer Law and Business, 2012): 57.

Note 28. Merrill, supra note 1 at 113.

Note 29. JCM, supra note 3 at para 68.

Note 30. Merrill, supra note 1 at 111.

Note 31. JCM, supra note 3 at para 54.

Note 32. Ibid. at para 55.

Note 33. Ibid. at para 55-61.

Note 34. CC v AW, 2005 ABQB 290, 50 Alta LR (4th) 61.

Note 35. JCM, supra note 3 at para 55-57.

Note 36. Ibid. at para 57.

Note 37. Jonathan Yearworth and Ors v North Bristol NHS, [2009] EWCA Civ 37.

Note 38. JCM, supra note 3 at para 61.

Note 39. Ibid. at para 59.

Note 40. JCM, supra note 3 at para 44. 
Note 41. Hecht v The Superior Court of Los Angeles County, 16 Cal App (4th) 836 (Ct App 1993).

Note 42. Moore $v$ Regents of the University of California, 51 Cal (3d) 120 (Sup Ct 1990).

Note 43. Davis v Davis, 842 SW (2d) 588 (Sup Ct 1992).

Note 44. JCM, supra note 3 at para 43.

Note 45. Ibid. at para 66.

Note 46. Ibid.

Note 47. Merrill, supra note 1 at 118.

Note 48. Ibid. at 113 .

\section{Copyrights}

Copyright for this article is retained by the author(s), with first publication rights granted to the journal.

This is an open-access article distributed under the terms and conditions of the Creative Commons Attribution license (http://creativecommons.org/licenses/by/3.0/). 